\title{
Telmatogeton ScHINER, 1866 (Chironomidae: Diptera), a newly recorded genus of chironomid larva for the Egyptian Mediterranean Fauna
}

\author{
KHALED MAHMOUd ABDELSALAM* \\ National Institute of Oceanography and Fisheries, Alexandria, Egypt
}

\begin{abstract}
Sampling of fouling organisms carried out during January 2019 at Al-Max (west of the city of Alexandria) on the Mediterranean coast of Egypt revealed the presence of larval populations belonging to the genus Telmatogeton (Chironomidae), which is reported for the first time from the Mediterranean coast of Egypt. The larvae were found among clumps of fine filamentous green algae (Enteromorpha compressa). A description of the larva with taxonomic remarks and comments on its ecology and geographical distribution are given.
\end{abstract}

KEY WORDS: Diptera, Chironomidae, Telmatogeton SCHINER, 1866, systematics, Mediterranean coast, Egypt.

\section{INTRODUCTION}

There are more than 20000 species of Chironomidae (non-biting midges) in the world (SHARMA \& GUPTA 2014), making it the most diverse family among the aquatic dipteran insects. The chironomid fauna of Europe includes 1262 species (SÆTHER \& SPIES 2013). The duration of the larval stage in Chironomidae is the longest among insects, compared with the short-lived adults. Chironomid larvae play an important role in the production and transformation of benthic biomass in aquatic environments (THORP \& COVICH 2010). They can survive in a wide range of conditions owing to their capacity to adjust to the physicochemical parameters of the surrounding water, representing fantastic signals of

\footnotetext{
*Corresponding author: kh.abdelsalam@gmail.com
} 
water quality (ROSENBERG \& RESH 1993). Moreover, in hypoxic conditions, chironomid larvae may be the only insects present in benthic sediments (ARMITAGE et al. 1995).

Marine larvae of aquatic insects, often scarce and cryptic, have been to a great extent ignored by marine biologists through exclusion from textbooks and marine biodiversity compilations (e.g. HowsOn \& Picton 1999, LEVINTON 2001, ARCHAMBAult et al. 2010). The non-biting midges (order Diptera) provide an exception, with a high number of marine species distributed among a large number of genera (CHENG 1976, NEUMANN 1976).

The genus Telmatogeton SCHINER, 1866 is affiliated to the subfamily Telmatogetoninae WIRTH, 1949, previously known as Clunioninae. Telmatogetoninae used to be regarded as a homogeneous phylogenetic group derived from the Orthocladiinae (USINGER 1957). At present, it forms a sister group of the remaining chironomid subfamilies in all cladograms (SÆTHER 2000).

Although some larvae of chironomid taxa are confined to marine habitats (e.g. the genera Thalassomya SCHINER, 1856, Clunio HALIDAY, 1855 and Thalassosmittia STRENZKE \& REMMERT, 1957), other larvae can be found in all types of aquatic habitats (marine, brackish and freshwater). Species of the genus Telmatogeton are examples from the last-mentioned type, which appear to be transitional between marine and freshwater environments (WIRTH 1947).

Worldwide, there are 28 species of the genus Telmatogeton (ANDERSEN et al. 2013): Telmatogeton abnormis (TERRY, 1913), T. alaskensis COQUILLETT, 1900, T. amphibius (EATON, 1875), T. antipodensis SUBletTe \& WIRTH, 1980, T. atlanticum OliveIRA, 1950, T. australicus WOMERSLEY, 1936, T. eshu OLIVEIRA, 2000, T. fluviatilis WIRTH, 1947, T. hirtus WIRTH, 1947, T. japonicus TOKUNAGA, 1933, T. latipennis WIRTH, 1949, T. macswaini WIRTH, 1949, T. macquariensis (BRUNDIN, 1962), T. magellanica (JACOBS, 1900), T. minor KIEFFER, 1914, T. mortoni LEADER, 1975, T. murrayi SÆTHER, 2009, T. nanum OliveIRA, 1950, T. pacificus ToKUNAGA, 1935, T. pectinatus (DEBy, 1889), T. pusillum EDWARDS, 1935, T. sancti-pauli SCHINER, 1866, T. simplicipes EDWARDS, 1931, T. spinosus (HASHIMOTO, 1973), T. torrenticola (TERRY, 1913), T. trilobatus (KIEFFER, 1911), T. trochanteratum EDWARDS, 1931 and T. williamsi WIRTH, 1947. According to OLIVEIRA (1950), only five species can live in freshwater on waterfall stones: T. abnormis, T. fluviatilis, T. hirtus, T. torrenticola and T. williamsi.

According to Fauna Europaea (SÆTHER \& SPIES 2013), there are only three European species in the genus Telmatogeton: T. japonicus TOKUnAGA, 1933 - the marine splash midge (distributed worldwide), T. murrayi SÆTHER, 2009 (Iceland and the British Isles (LANGTON \& HANCOCK 2013, LANGTON 2015)) and T. pectinatus (DEBy, 1889) (Britain and French mainland).

There have been few studies of marine dipteran larvae in the Egyptian waters. The first record of a chironomid larva (Clunio sp.1) from Hurghada, Egyptian Red Sea, investigated 
by ABDELSALAM (2017), could belong to a species new to science. Recently, ABDELSALAM (2019) studied the first record of a larva of the dipteran genus Aphrosylus HALIDAY, 1851 (Dolichopodidae) from the Abu Qir area, Egyptian Mediterranean Sea. However, no immature stages of Telmatogetoninae (Chironomidae) have been recorded before in Egypt, so the present study documents the first record of chironomid larvae of the genus Telmatogeton SCHINER, 1866 from the Al-Max area, west of the city of Alexandria, on the Egyptian Mediterranean coast. A full morphological description of the larva is provided, supplied with taxonomic comments, distribution and habitat.

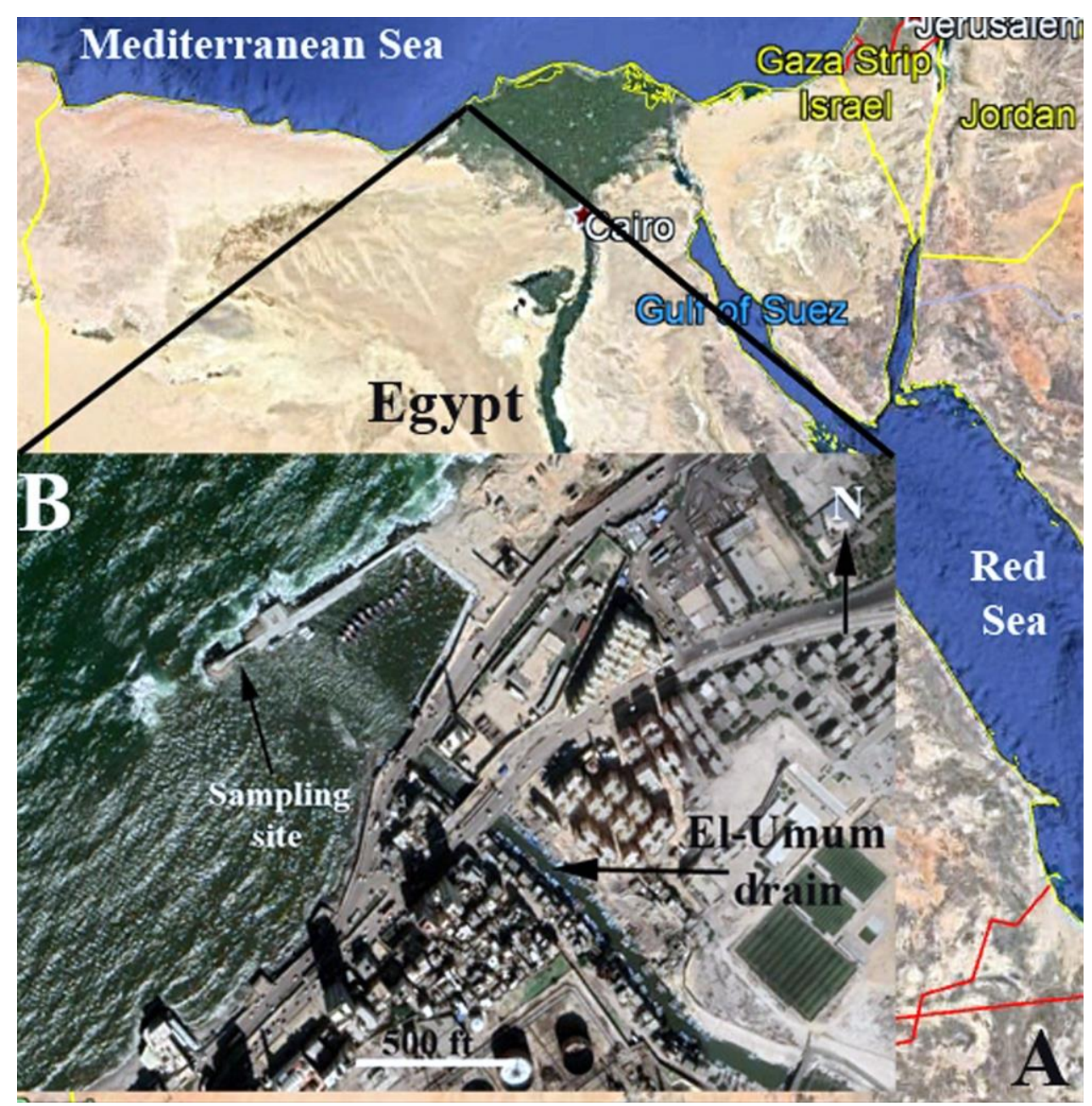

Fig. 1. Map of Egypt (A) showing the location of the sampling site on the Mediterranean coast of the Al-Max area (B). 


\section{MATERIAL AND METHODS}

In January 2019, samples of marine fouling organisms were scraped from the surface of submerged cubic cement blocks near the outfall of the El-Umum drain in the El-Max area, west of Alexandria, on the Mediterranean coast of Egypt (Fig. 1). Most of the surfaces of these cement blocks were covered by a dense mat of green algae (Enteromorpha compressa). The sampling site (salinity $4 \sim 5 \%$ ) received drainage water in varying amounts and frequency from the El-Umum drain.

The fouling samples were anaesthetized with $7 \%$ aq. magnesium chloride and subsequently preserved in $7 \%$ formalin. During the examination, a considerable number of chironomid larvae were found and isolated for identification. These larvae were cleared in $10 \%$ aq. sodium hydroxide $(\mathrm{NaOH})$ for examination under an Optika compound microscope (total magnification up to $1000 \mathrm{x}$ ). Illustrations of some anatomical parts were made under a microscope equipped with a camera lucida. Microphotographs of the chironomid larva were taken with a Nikon D-5200 digital camera attached to the stereoand/or compound microscopes.

The following scientific articles were consulted for the identification of the species (WILliams 1944, WIRTH 1947, 1949, ARMITAGE et al. 1995 and ANDERSEN et al. 2013). The terminology of the larval morphological features generally follows that of ANDERSEN et al. (2013).

\section{RESULTS}

Class: Insecta

Order: Diptera

Suborder: Nematocera

Family: Chironomidae

Subfamily: Telmatogetoninae WIRTH, 1949

Genus: Telmatogeton SCHINER, 1866

Telmatogeton sp.

Figs (2-11)

Telmatogeton SCHINER, 1866: 931. WIRTH (1947).

Synonyms

=Halirytus EATON, 1875

=Psamathiomya DEBY, 1889

=Jacobsiella RÜBSAAMEN, 1906 
=Paraclunio KIEFFER, 1911

=Charadromyia TERRY, 1913

=Trissoclunio KIEFFER, 1920

\section{Material examined}

14 larvae were collected from an area of about $\left(0.5 \mathrm{~m}^{2}\right)$ on submerged cement blocks in the Al-Max area. The larvae varied in length between 8 and $11 \mathrm{~mm}$.

\section{Description}

Larvae large, yellowish-brown in colour (Fig. 2A). Thorax and abdomen with minute setae, except for the two pairs of long anal setae on the ninth abdominal segment. No procerci, and anal gills and tubules absent (Fig. 2C).

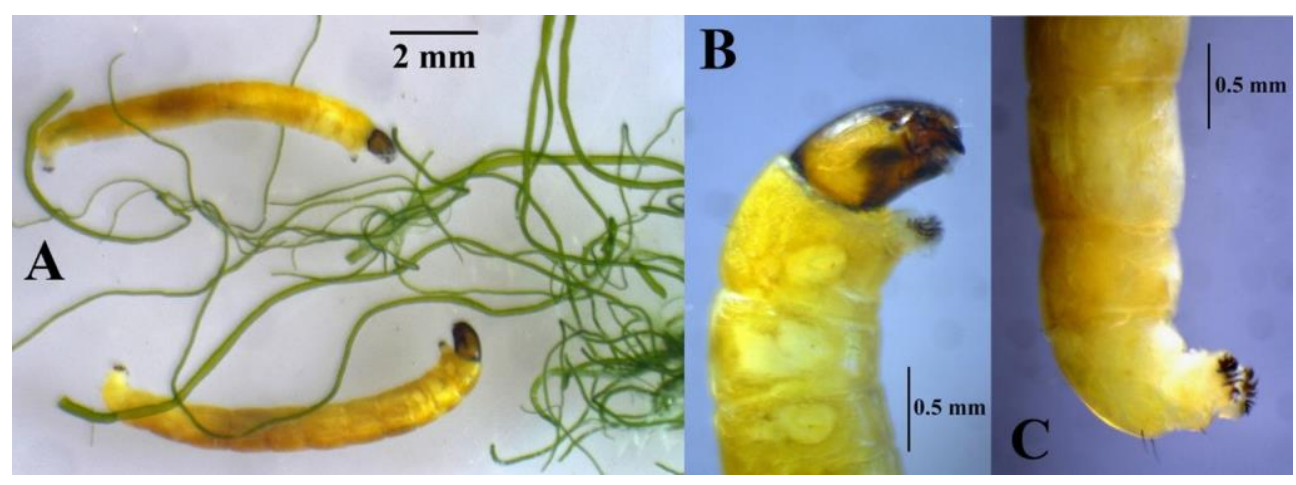

Fig. 2. Larvae of Telmatogeton sp. A, among green algae Enteromorpha compressa; $\mathbf{B}$, head and anterior pseudopod; $\mathbf{C}$, posterior end.

\section{Head \& mouth parts}

Head distinct, well chitinized (Fig. 2B, Fig. 3A). Paired eye spots. Two well developed medial sclerites (one larger trapezoidal and one smaller semicircular) anterior to apotome, the remaining area granulate without delimited sclerites (Fig. 3B). Ventrally, head without ventromental plate or beard beneath (Fig. 3A).

Antenna: Short, 4-segmented; large basal segment, about $1.3 \mathrm{x}$ as long as wide (measured example - length: $59 \mu \mathrm{m}$, width: $45 \mu \mathrm{m}$ ). Very short flagellum, with apparently unequal bifid blade (Fig. 4A), sub-equal to flagellum. Antennal ratio about 1.25. Lauterborn organ small and style weak (Fig. 4B). 


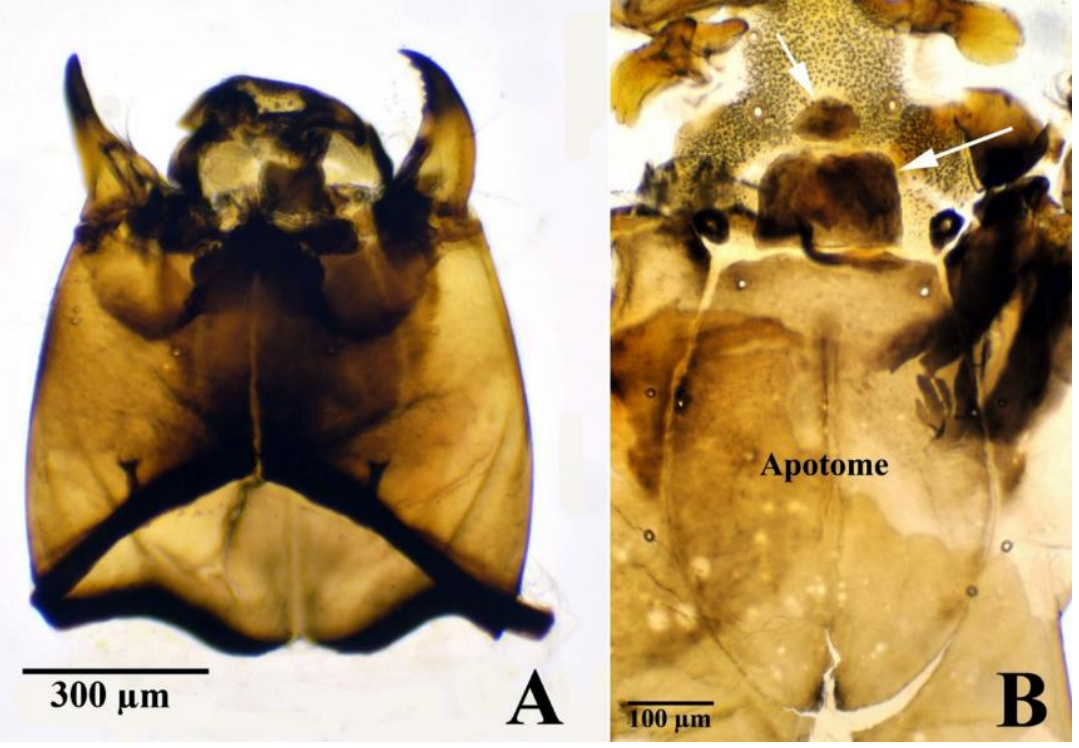

Fig. 3. Larva of Telmatogeton sp. Head capsule: A, ventral view; B, dorsal view, apotome of the head with its anterior medial sclerites (arrows).

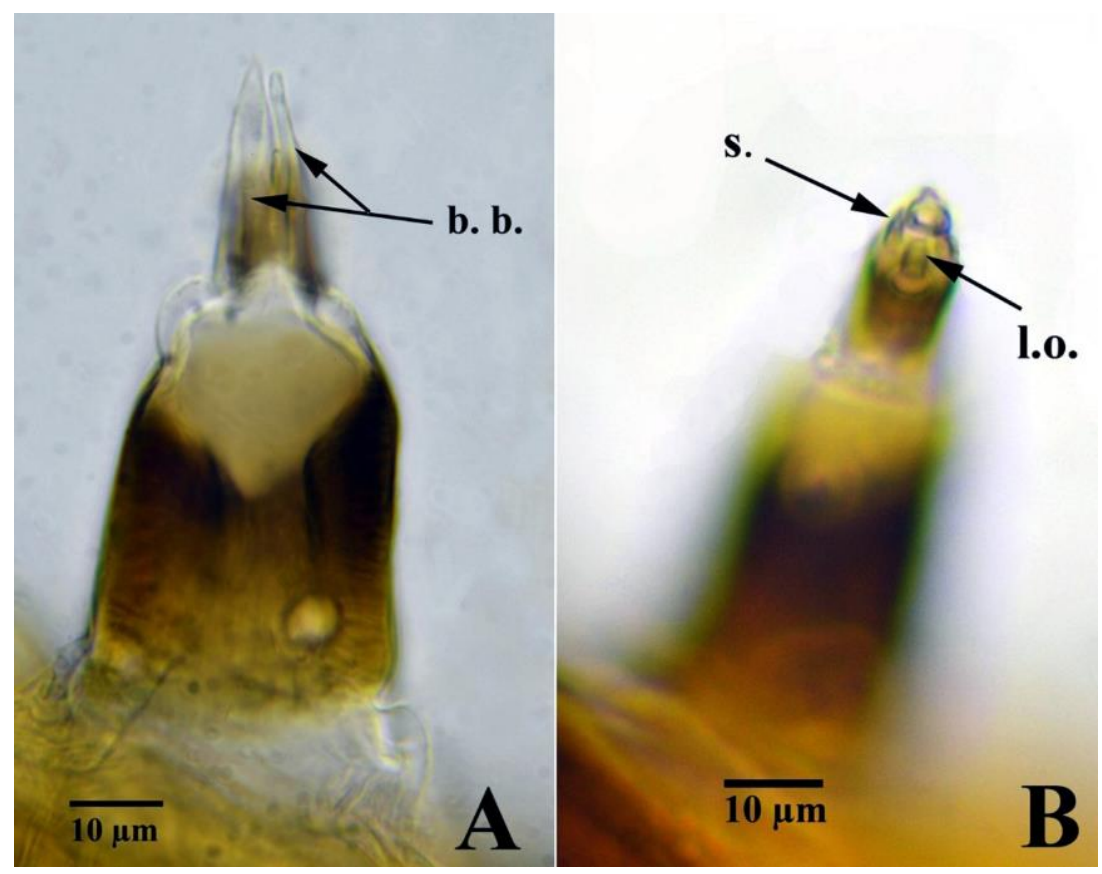

Fig. 4. Larva of Telmatogeton sp. Antenna. A, bifid blade, (b.b.); B, Lauterborn organ, (1.o.); style, (s.). 
Labrum: All S setae well-developed, simple, especially S III (Fig. 5A), without labral lamellae, but anterior labral margin apparently 3-lobed. Chaetae in tufts of simple and/or serrate chaetae. Pecten epipharyngis composed of 3 subequal scales, each with variablesized teeth (Fig. 6A). Heavily sclerotized premandible, with three blunt apical teeth, supported with well advanced brush (Fig. 5B).

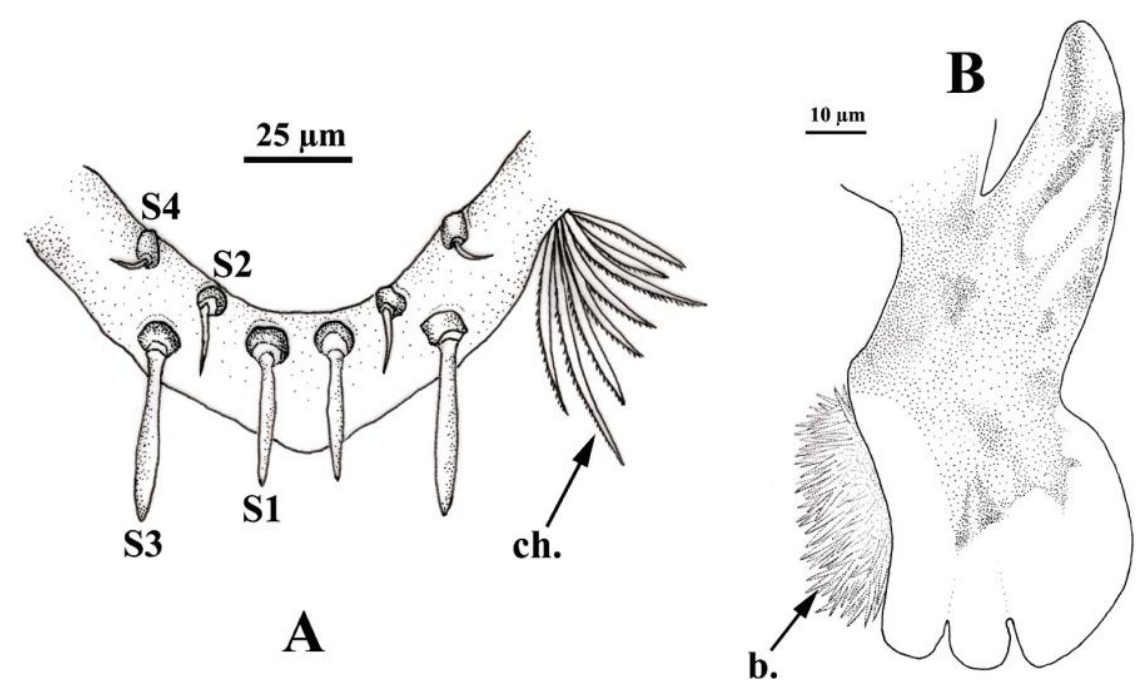

Fig. 5. Larva of Telmatogeton sp. Mouth parts. A, Simple S setae of labrum, and chaetae (ch.); B, Premandible with brush (b.).

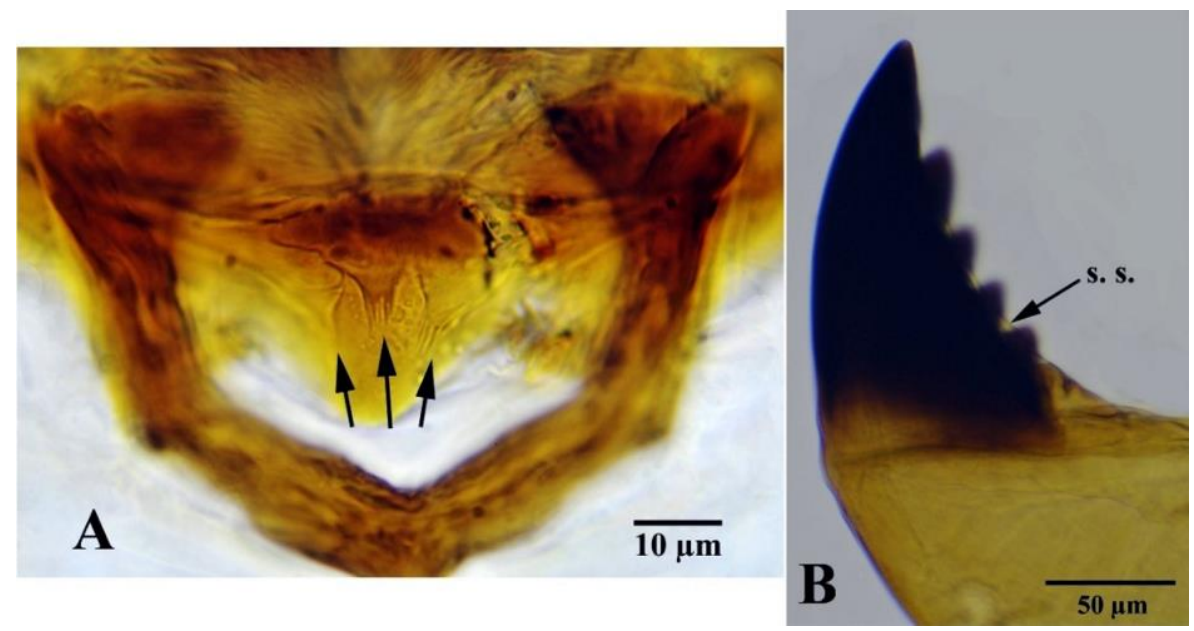

Fig. 6. Larva of Telmatogeton sp. Mouth parts. A, Pecten epipharyngis with 3 subequal scales (Arrows); B, the five-toothed mandible, with long seta subdentalis (s.s.). 
Mandible: Heavily sclerotized, with five darkened teeth, the largest being the apical one. Long seta subdentalis but no pecten mandibularis (Fig. 6B). Also 6-7 fine, simple branched setae internae and 2 lateral setae.

Mentum: Single large median pointed tooth; with variable number of lateral tooth pairs (5 7), decreasing outwards, the outermost one minute (Fig. 7). Prementum with dense median brush of featherlike setae (Fig. 8). Without distinct ventromental plate; beard absent.

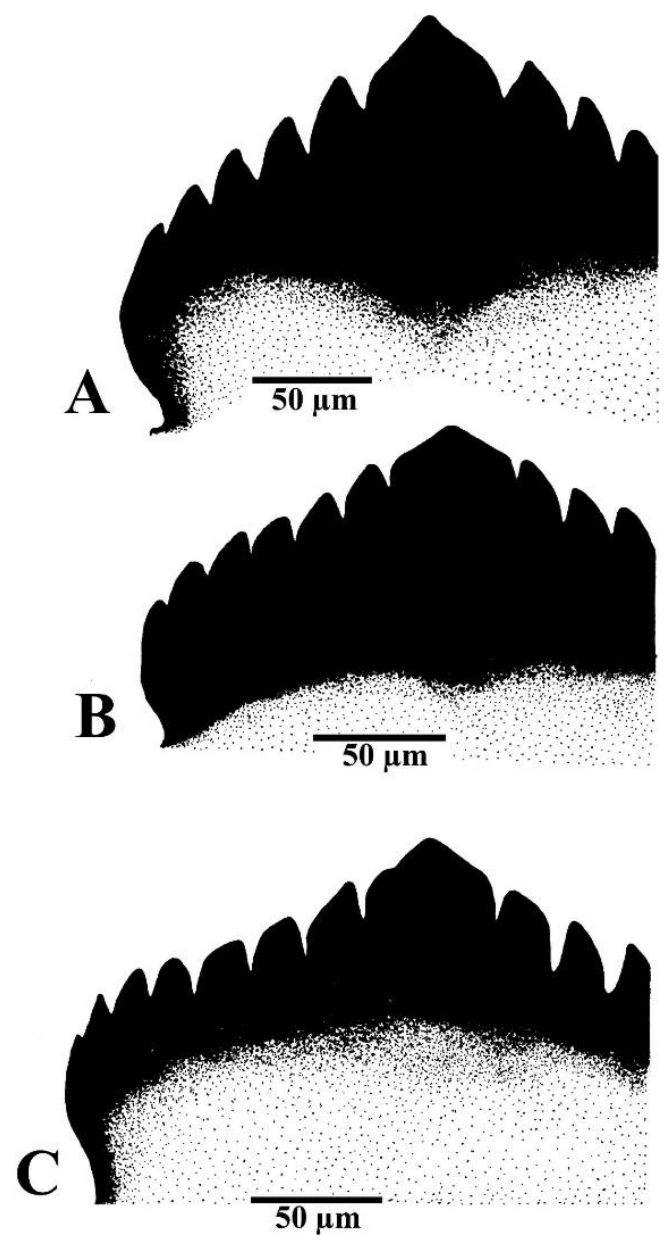

Fig. 7. Larva of Telmatogeton sp. Variation in the mentum. A, Five lateral teeth; B, Six lateral teeth; $\mathbf{C}$, Seven lateral teeth. 


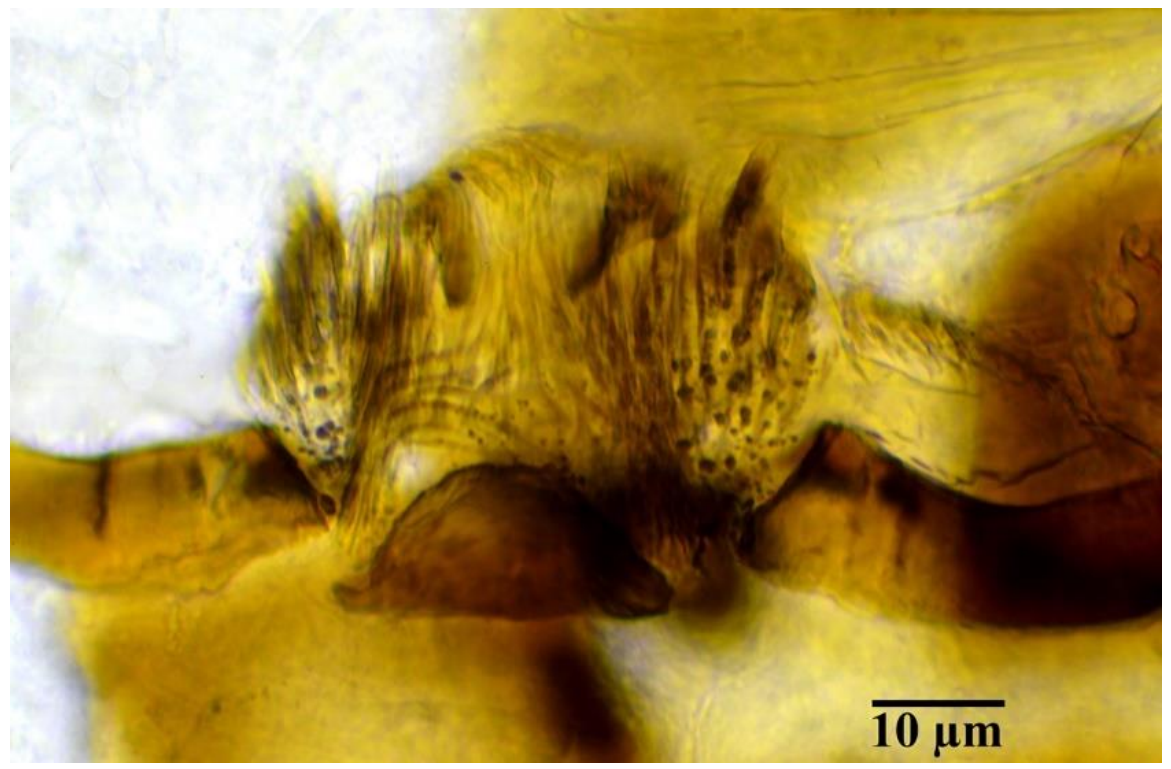

Fig. 8. Larva of Telmatogeton sp. Hypopharynx and prementum.

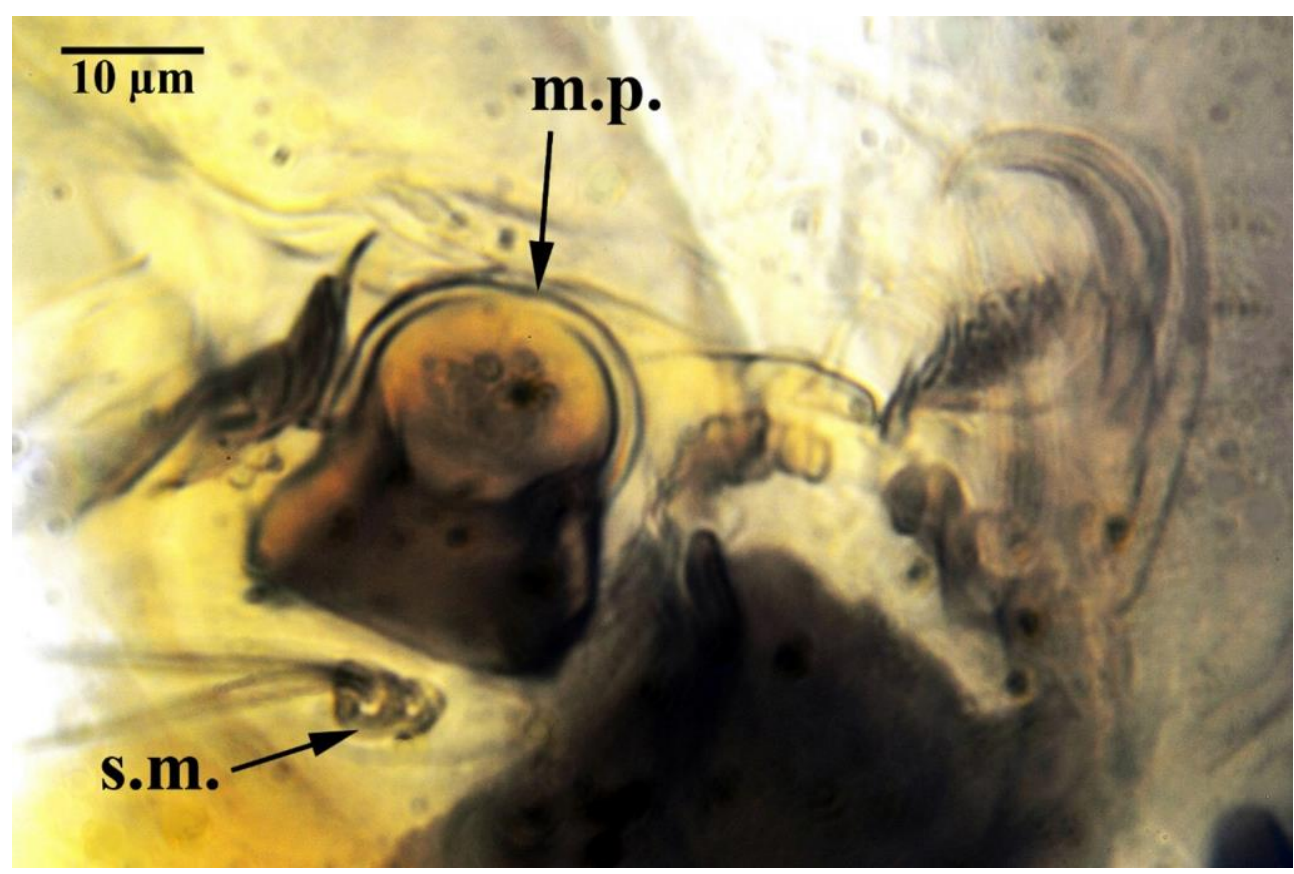

Fig. 9. Larva of Telmatogeton sp. Maxilla, ventral view; maxillary palp (m.p.); setae maxillaris (s.m.). 
Maxilla: Almost triangular in shape, with short one segment maxillary palp bearing small sensillae and setae apically. Ventrally outer margin of palpiger bears variable numbers of lamellae (tetrahedral, simple or apically serrate). Galea apparently without lamellae or pecten galearis, but sensillae and setae well developed with two setae maxillaris (Fig. 9).

\section{Thorax}

The anterior three segments form the thorax. Prothorax with anterior pseudopod shallowly bilobed, each flap with gradually developed apical crown of narrow hooks (Fig. 10).

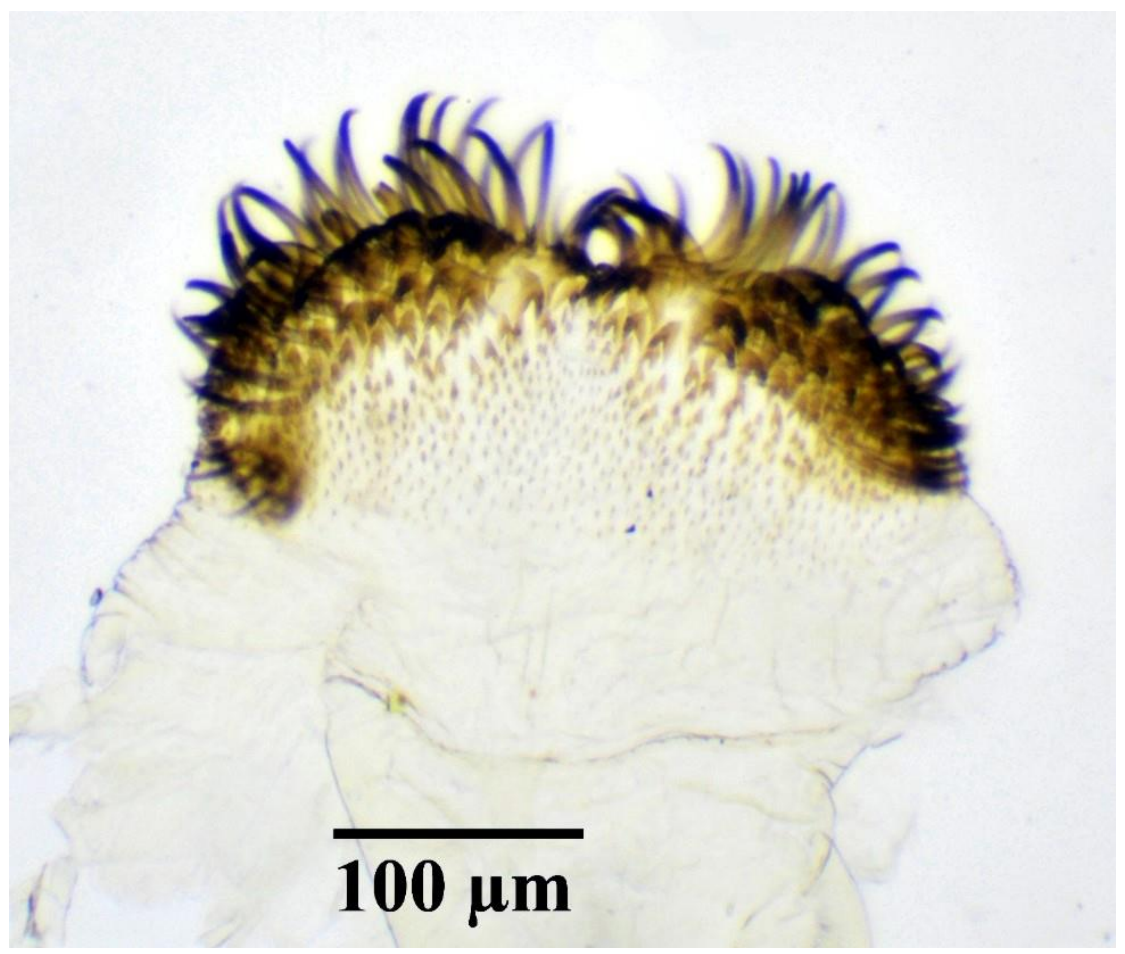

Fig. 10. Larva of Telmatogeton sp. Anterior pseudopod.

\section{Abdomen}

Segments four to twelve comprise the abdomen. Posterior pseudopods, each with 19-21 acute curved sickle-like hooks, gradually increase in size towards the apex (Fig. 11). 


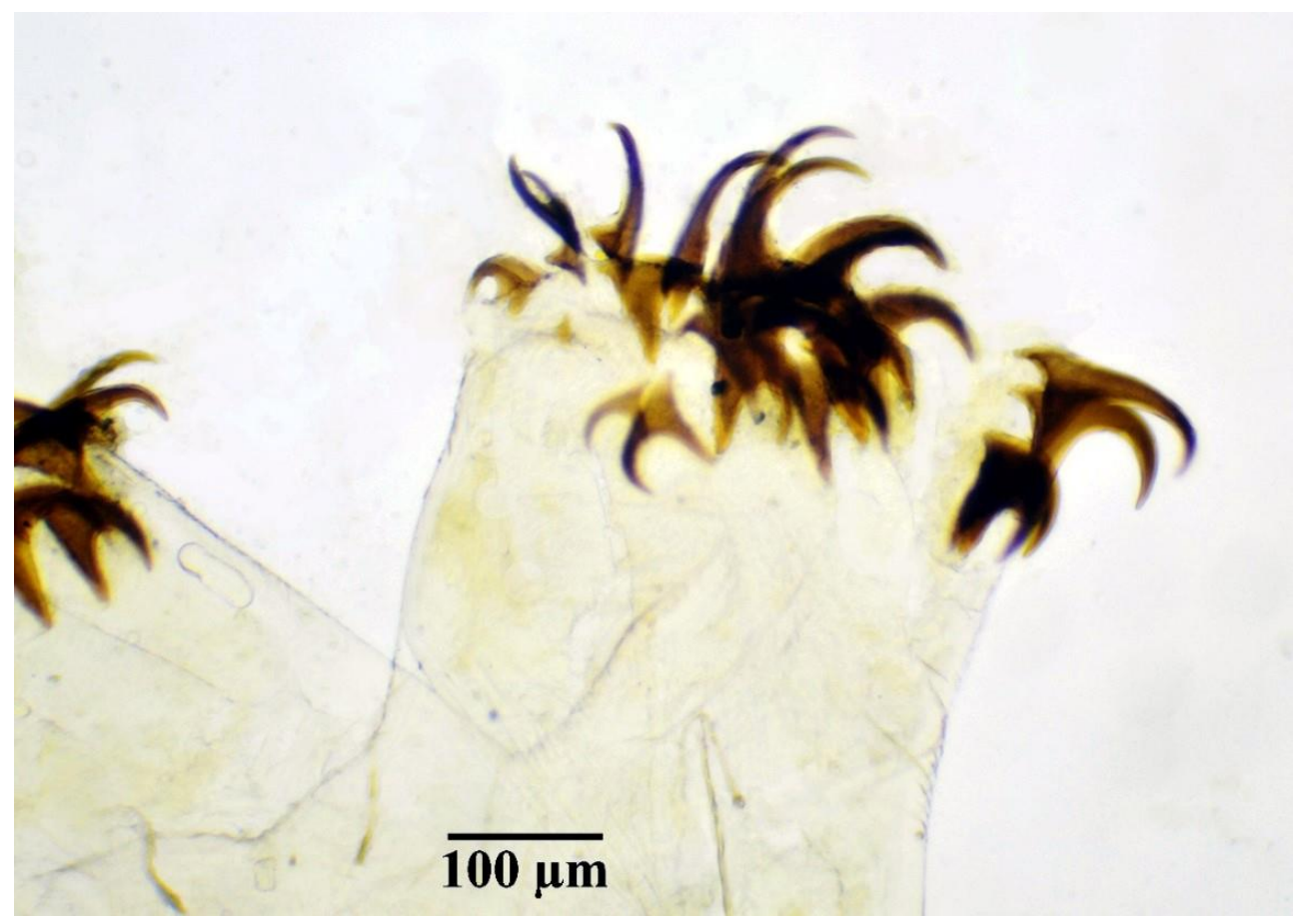

Fig. 11. Larva of Telmatogeton sp. Posterior pseudopod.

\section{Ecology and distribution}

In the present study, larvae of the genus Telmatogeton were found among clumps of fine filamentous green algae (Enteromorpha compressa (L.) NEES), which cover submerged cement blocks in the Al-Max area. The salinity at the sampling site was 4 5\%, indicating brackish water. However, species of the genus Telmatogeton in the intertidal environment often settle in habitats where freshwater mixes with the sea (WIRTH 1947), and thus are marine species that tolerate brackish waters (COLBO 1996).

According to Cranston (1989), Oliver et al. (1990), Colbo (1996), Ashe \& O’CONNOR (2012), Moubayed-BreIl \& ASHe (2012) and SÆTHER \& SPIES (2013), $T$. japonicus is globally the most widely distributed species, including all European coasts, and the Australasian, Eastern Palaearctic, Nearctic and Oriental regions.

However, in the laboratory, TOKUNAGA (1935) tracked the development of $T$. japonicus from larvae to adults in freshwater. RAUNIO et al. (2009) reported the extensive distribution of this species in the Baltic Sea, which has established fertile populations in fresh to brackish (salinity $<4 \%$ ) coastal habitats. $T$. japonicus can live on ships' hulls and is most likely transported far and wide by shipping (SÆTHER 2009). 
However, the present larval record of Telmatogeton sp. is the first from the Al-Max area on the Alexandria coast, representing an addition to the list of fauna in the Egyptian Mediterranean Sea.

\section{DISCUSSION}

Chironomidae is a very diverse group. However, larvae of the subfamily Telmatogetoninae could be confused with some orthocladiine larvae, but can be definitively identified by the dense median brush on the prementum, short antennae and the absence of procerci (EPLER 2001). Within the Telmatogetoninae, larvae of the genus Telmatogeton SCHINER, 1866 can be distinguished from the similar congenic genus Thalassomya SCHINER, 1856 by the following: 1) Telmatogeton has two well-developed medial sclerites (a larger trapezoidal one and a smaller semicircular one) anterior to the apotome (the anterodorsal part of the head); Thalassomya has no such sclerites; 2) in Telmatogeton the premandible has 3 blunt apical teeth, but in Thalassomya it is simple.

In the current investigation, careful examination of six larvae showed that the menta of three larvae (50\%) had 13 teeth, the menta of two (33\%) had 15 teeth, and the mentum of the other individual (16\%) with 11 teeth. On the other hand, all the mandibles have 5 teeth. TOKUNAGA (1935) and WIRTH (1947) reported that the larval stage of T. japonicus has a mentum with eleven teeth and a mandible with seven sharp teeth.

REMMERT (1963), who described the larva of a new species (T. remanei) from Germany, reported that this Palearctic species was at first confused with $T$. japonicus, but that examination demonstrated that $T$. remanei larvae had 5 mandibular teeth and $T$. japonicus larvae had 7 mandibular teeth. On the other hand, the mentum of both species possesses 5 teeth on each side of the large central tooth. REMMERT (1963) also maintained that the teeth of the mentum and mandible wear down only very slowly with eating, so they can have a very aberrant appearance. EPLER (2001) reported larvae of T. japonicus from eastern North America with a 15-toothed mentum and a 5-toothed mandible. His finding might depend on the fact that $T$. gedanensis SZADZIEWSKI 1977 is a junior synonym of $T$. japonicus. SZADZIEWSKI (1977) described the larval stage of the new species (T. gedanensis) with the larval mandible armed with six blunt distal teeth and the mentum with fifteen teeth.

Based on the fact that both $T$. remanei (REMMERT 1963) and T. gedanicus (SZADZIEWSKI 1977) (previously known as T. gedanensis SZADZIEWSKI 1977) are considered to be junior synonyms of T. japonicus (KRONBERG 1986, DE JONG et al. 2007), coupled with the finding of EPLER (2001), it is reasonable to tentatively identify the examined larva as $T$. japonicus. 
Although the examined larvae closely resemble $T$. japonicus, it is hard to be absolutely sure of the identification without collecting pupae and/or adults from the sampling site. Indeed, three sampling trips to Al-Max site were made, one every ten days, to collect pupae or pupal exuviae but, unfortunately, none were found. It is well known that pupae or pupal exuvial samples can be used to definitively identify a specimen to the species level (LANGTON \& VISSER 2003).

More intense investigations and sampling efforts are needed in order to determine the full biodiversity of dipteran insect larvae on Egyptian coasts.

\section{REFERENCES}

Abdelsalam Kh.M. 2017. The genus Clunio Haliday, 1855 from Egypt (Hurghada, Red Sea) with a description of the larva of Clunio sp.1 (Diptera, Chironomidae, Orthocladiinae). Polish Journal of Entomology, 86 (1): 39-47.

Abdelsalam Kh.M. 2019. First record of a larva of the dipteran genus Aphrosylus Haliday, 1851 (Dolichopodidae) from the Egyptian Mediterranean Sea. Polish Journal of Entomology, 88 (1): 79-92.

Andersen T., Cranston P.S., Epler J. H. (eds.) 2013. Chironomidae of the Holarctic Region: Keys and Diagnoses. Part 1. Larvae. Insect Systematics and Evolution, Supplement No. 66: 1-571.

Archambault P., Snelgrove P.V.R., Fisher J.A.D., Gagnon J.-M., Garbary D.J., Harvey M., Kenchington E.L., Lesage V., Levesque M., Lovejoy C., Mackas D.L., McKindsey C.W., Nelson J.R., Pepin P., Piché L., Poulin M. 2010. From Sea to Sea: Canada's Three Oceans of Biodiversity. PLoS ONE, 5 (8): e12182.

Armitage P.D., Cranston P.S., Pinde L.C.V. 1995. The Chironomidae: Biology and ecology of non-biting midges. Chapman \& Hall, Andover.

ASHE P., O’CONNOR J.P. 2012. A World Catalogue of Chironomidae (Diptera). Part 2. Orthocladiinae. Irish Biogeographical Society \& National Museum of Ireland, Dublin.

BRUNDIN L. 1962. Insects of Macquarie Island. Diptera: Chironomidae. Pacific Insects, 4 (4): 945-954.

Cheng L. 1976. Marine insects 1. North-Holland Publishing Company, Amsterdam.

Colbo M.H. 1996. Chironomidae from marine coastal environments near St. John's, Newfoundland, Canada. Hydrobiologia, 318 (1-3): 117-122.

Coquillett D.W. 1900. Papers from the Harriman Alaska Expedition. Entomological Results (3): Diptera. Proceedings of the Washington Academy of Sciences, 2: 389-464.

CRANSTON P.S. 1989. The adult males of Telmatogetoninae (Diptera: Chironomidae) of the Holarctic region - Keys and Diagnosis. [in:] T. WeIDERHOLM (ed.), Chironomidae of the Holarctic region Keys and Diagnosis. Part 3. Adult males. Entomologica Scandinavica, Supplement 34: 17-21.

De Jong H., SAether O.A., Spies M. 2007. Fauna Europaea, Chironomidae (Diptera). [in:] Fauna Europaea Ver 1.3. Internet: http://www.faunaeur.org. 
Deby J. 1889. Description of a new dipterous insect, Psamathiomyia pectinata. Journal of the Royal Microscopical Society, 2: 180-186.

EATON A.E. 1875. Notes on the entomology of Kerguelen's Island. Entomologist's Monthly Magazine, 12: 1-2.

EDwards F.W. 1931. Chironomidae. [in:] Diptera of Patagonia and South Chile. Part II, fascicle 5. British Museum (Natural History), London, 233-331.

EDWARDS F.W. 1935. Mycetophilidae, Culicidae, and Chironomidae, and additional records of Simuliidae from the Marquesas Islands. Bernice P. Bishop Museum - Bulletin, 114: 85-92.

EPLER J.H. 2001. Identification manual for the larval Chironomidae (Diptera) of North and South Carolina. St. Johns River Water Management District,. Palatka, FL.

HALIDAY A.H. 1851. Diptera. Empididae. Dolichopodidae. Syrphidae. [in:] F. WALKER (ed.). Insecta Britannica, Diptera. Volume 1. (q.v.). Reeve and Benham, London, 1-9, 85-144, 144-221, 234-303.

HALIDAY A.H. 1855. Descriptions of insects figured, and references to plates illustrating the notes on Kerry insects. Natural History Review, 2: 59-64.

Hashimoto H. 1973. A New Species of the Marine Chironomid Paraclunio (Diptera) from Southern California. Annotationes Zoologicæ Japonenses, 46: 266-273.

Howson C.M., Picton B.E. 1999. The species directory of the marine fauna and flora of the British Isles and surrounding seas. CD-ROM edition. Ulster Museum and The Marine Conservation Society, Belfast and Ross-on-Wye.

JACOBS J.C. 1900. Diptera. Diagnoses d'insectes recueillis par l'Expédition antarctique Belge. Diptera. Annales de la Société Entomologique de Belgique, 44: 106-107.

KIEFFER J.J. 1911. Description d'un chironomide d'Amérique formant un genre nouveau. Bulletin de la Société d'Histoire Naturelle de Metz, 27: 103-105.

KIEFFER J.J. 1914. South African Chironomidae. Annals of the South African Museum, 10: 259-270.

KIEFFER J.J. 1920. A new genus of chironomid (Diptera) from the Cape. Annual Society of African Museum, 17: 523-525.

KRONBERG I. 1986. Riesenchromosomen und Artareal einer baltischen Telmatogeton-Art (Diptera: Chironomidae: Telmatogetoninae). Zeitschrift für zoologische Systematik und Evolutionsforschung, 24 (3): 190-197.

LANGTON P.H. 2015. Telmatogeton murrayi (Diptera, Chironomidae) new to Ireland. Dipterists Digest, 22 (1): 16.

LANGTON P.H., HANCOCK E.G. 2013. Telmatogeton murrayi SÆTHER and T. japonicas ToKUNAGA (Diptera, Chironomidae) new to Britain. Dipterists Digest, 20 (2): 157-160.

LANGTON P.H., Visser H. 2003. Chironomidae Exuviae. A key to pupal exuviae of the West Palaearctic Region. ETI University of Amsterdam World Biodiversity Database CD-ROM series.

LEADER J.P. 1975. Three new chironomids (Diptera: Chironomidae) from the New Zealand seashore. New Zealand Journal of Zoology, 2 (2): 209-214.

LEVINTON J.S. 2001. Marine biology: function, biodiversity, ecology. $2^{\text {nd }}$ edition. Oxford University Press, Oxford. 
Moubayed-Breil J., Ashe P. 2012. An updated checklist of the Chironomidae of Corsica with an outline of their altitudinal and geographical distribution (Diptera). Ephemera 13 (1): 13-39.

Neumann D. 1976. Adaptations of chironomids to intertidal environments. Annual Review of Entomology, 21: 387-414.

OLIVEIRA S.J. de 1950. Sôbre duas novas espécies neotrópicas do gênero Telmatogeton SchINER, 1866 (Diptera, Chironomidae). Memórias do Instituto Oswaldo Cruz, 48: 469-485.

OliveIRA S.J. de 2000. Contribution to the knowledge of the Brazilian marine chironomids. I. Description of a new species of the genus Telmatogeton SCHINER, 1866 (Diptera, Chironomidae, Telmatogetoninae). [in:] O. HofFrICHTER (ed.). Late $20^{\text {th }}$ Century research on Chironomidae. An anthology from the $13^{\text {th }}$ International Symposium on Chironomidae, Freiburg, 5-9 September 1997. Shaker Verlag, Aachen, 197-200.

Oliver D.R., Dillion M.E., Cranston P.S. 1990. A catalog of the Nearctic Chironomidae. Research Branch, AgriCulture Canada, Ottawa. Publication 1857B. AgricultureCanada, Ottawa.

Raunio J., PaAsivirta L., Brodin Y. 2009. Marine midge Telmatogeton japonicus TokUnaga (Diptera: Chironomidae) exploiting brackish water in Finland. Aquatic Invasions, 4 (2): 405-408.

REMMERT H. 1963. Telmatogeton remanei n. sp., eine neue marine Chironomide aus der Kieler Förde. Zoologischer Anzeiger, 171 (5-8): 165-178.

Rosenberg D.M., ReSH V.H. 1993. Introduction to freshwater biomonitoring and benthic macroinvertebrates. [in:] D.M. RosenberG, V.H. ReSH (eds.). Freshwater biomonitoring and benthic macroinvertebrates. Chapman and Hall, London, 1-9.

RÜbSAAmen E.H. 1906. Diptères. Chironomidae. Expédition Antarctique Belge. Résultats du Voyage du S.Y. Belgica, 1897-1898-1899. Rapports scientifiques, zoologie, Annales de la Société Entomologique de Belgique 44: 75-85.

SÆTHER O.A. 2000. Phylogeny of the subfamilies of Chironomidae (Diptera). Systematic Entomology, 25 (3): 393-403.

SÆTHER O.A. 2009. Telmatogeton murrayi sp. n. from Iceland and T. japonicus Tokunaga from Madeira (Diptera: Chironomidae). Aquatic insects, 31 (1): 31-44.

SÆther O.A., SPIES M. 2013. Fauna Europaea: Chironomidae. [in:] T. PAPE, P Beuk (eds.). Fauna Europaea: Diptera, version 2.6. Intenret: http://www.faunaeur.org

SCHINER J.R. 1856. Anmerkungen zu dem im Bande V, pag. 13 dieser Verhandlungen abgedruckten Aufsätze FRAUENFELD's: Beitrag zur Insecten-Geschichte. Verhandlungen des ZoologischBotanischen Vereins in Wien, 6 :215-224.

SCHINER J.R. 1866. Bericht über die von der Weltumseglungsreise der k. Fregatte Novara mitgebrachten Diptera. Verhandlungen der Kaiserlich-Königlichen Zoologisch-Botanischen Gesellschaft in Wien, 16: 927-934.

Sharma M.R., Gupta V. 2014. Morphological Identification of Chironomus Larvae in Jaipur District (Rajasthan) India. International Journal of Scientific Research, 3 (9): 411- 413.

StrenZKe K., Remmert H. 1957. Terrestrische Chironomiden. XVII. Thalassosmittia thalassophila (BEQU. u. GOETGH.). Kieler Meeresforschungen, 13 (2): 263-273.

Sublette J.E., Wirth W.W. 1980. The Chironomidae and Ceratopogonidae (Diptera) of New Zealand's subantarctic islands. New Zealand Journal of Zoology, 7 (3): 299-378. 
SZADZIEwSKI R. 1977. Telmatogeton gedanensis sp. n. (Clunioninae, Chironomidae, Diptera), new marine chironomid from the Polish Baltic Coast. Polish Journal of Entomology, 47 (2): 175-184.

TERRY F.W. 1913. On a new genus of Hawaiian chironomids. Proceedings of the Hawaiian Entomological Society, 2: 291-295.

ThORP J.H., Covich A.P. (eds.) 2010. Ecology and Classification of North American Freshwater Invertebrates. Academic Press, Cambridge, MA.

Tokunaga M. 1933. Chironomidae from Japan (Diptera): I. Clunioninae. Philippine Journal of Science, 51 (1): 87-100.

ToKunAGA M. 1935. Chironomidae from Japan (Diptera) IV. The early stages of a midge, Telmatogeton japonicus ToKUnAGA. Philippine Journal of Science, 57: 491-511.

USINGER R.L. 1957. Marine Insects. Memoirs - Geological Society of America, 67 (1): 1177-1182.

WiLliams F.X. 1944. Biological studies in Hawaiian water-loving insects, Part III. Diptera or Flies. D. Culicidae, Chironomidae, and Ceratopogonidae. Proceedings of the Hawaiian Entomological Society, 12 (1): 149-180.

WIRTH W.W. 1947. A review of the Genus Telmatogeton SCHINER, with descriptions of three new Hawaiian species (Diptera: Tendipedidae). Proceedings of the Hawaiian Entomological Society, 13 (1): 143-195.

WIRTH W.W. 1949. A revision of the Clunionine midges, with descriptions of a new genus and four new species (Diptera: Tendipedidae). University of California Publications in Entomology, 8 (4): $151-182$.

Womersley H. 1936. An interesting chironomid, Telmatogeton australicus sp. n. from a South Australian reef. Records of the Australian Museum, 5 (1): 439-443.

Received: 10 May 2019

Accepted: 16 July 2019 